1981-04-01

\title{
Proton Induced X-Ray Emission Analysis - A Complement to Analytical Methods Used in Environmental Studies
}

N. F. Mangelson

nolan_mangelson@byu.edu

D. J. Eatough

N. L. Eatough

L. D. Hansen

M. W. Hill

See next page for additional authors

Follow this and additional works at: https://scholarsarchive.byu.edu/facpub

Part of the Electrical and Computer Engineering Commons

\section{Original Publication Citation}

Mangelson, N. F., et al. "Proton Induced X-Ray Emission Analysis - A Complement to Analytical Methods used in Environmental Studies." Nuclear Science, IEEE Transactions on 28.2 (1981): 1378-81

\section{BYU ScholarsArchive Citation}

Mangelson, N. F.; Eatough, D. J.; Eatough, N. L.; Hansen, L. D.; Hill, M. W.; Lee, M. L.; Phillips, L. R.; Post, M. E.; Richter, B. E.; and Ryder, J. F., "Proton Induced X-Ray Emission Analysis - A Complement to Analytical Methods Used in Environmental Studies" (1981). Faculty Publications. 766.

https://scholarsarchive.byu.edu/facpub/766 accepted for inclusion in Faculty Publications by an authorized administrator of BYU ScholarsArchive. For more information, please contact ellen_amatangelo@byu.edu. 


\section{Authors}

N. F. Mangelson, D. J. Eatough, N. L. Eatough, L. D. Hansen, M. W. Hill, M. L. Lee, L. R. Phillips, M. E. Post, B. E. Richter, and J. F. Ryder 


\author{
N.F. Mangelson, D.J. Eatough, N.L. Eatough, L.D. Hansen, M.W. Hil1, M.L. Lee, \\ L.R. Phillips, M.E. Post, B.E. Richter and J.F. Ryder \\ Departments of Chemistry and Physics and the Thermochemical Institute Contribution No. 238, \\ Brigham Young University, Provo, Utah 84602 USA
}

\section{$\underline{\text { Summary }}$}

Particle induced $\mathrm{X}$-ray emission (PIXE) analysis is a highly versatile method of element analysis. Thus it is well suited for use as a complement to other methods of analysis in experimental programs requiring both chemical and elemental analyses. This paper reports some results of two projects where PIXE was used in conjunction with titration calorimetry, ion chromatography, atomic absorption spectroscopy, gas chromatography/mass spectrometry, X-ray fluorescence spectroscopy and some other methods. The first is a study of sulfur chemistry in a copper smelter plume. Arsenic was found to be a conservative tracer of the plume and was used for calculation of plume dilution. Calcium was found to be characteristic of the background or ambient aerosol and was used to correct particulate data for the background contribution. The use of both plume and ambient tracers and of data from other analytical methods noted above led to the determination of several aspects of the plume sulfur chemistry. The second project is a study of the effluents from a high-temperature, high-pressure entrained flow gasifier. The scrubber water and particulate matter entrained in the scrubber water and in the product gas were analyzed by PIXE. Of particular interest were the low elemental concentrations in the scrubber water.

\section{Introduction}

Particle induced X-ray emission (PIXE) analysis is an excellent method for determining the elements heavier than aluminum which occur in samples at concentrations on the order of a part per million or greater. This paper reports results of two studies where PIXE methods of analysis were used with a number of other analytical methods in order to meet the objectives of the studies.

PIXE analysis techniques have only been applied for about ten years. New techniques and applications of PIXE are frequently reported. Excellent summaries of PIXE work are the review of Johansson and Johansson ${ }^{1}$ and the proceedings of two international conferences. ${ }^{2}, 3$

Considerable benefit can be realized from element analyses provided by PIXE when used in an analytical program with other methods of analysis. For example chemical studies related to environmental problems often require identification determination of gases, organic compounds and inorganic chemical species as well as elemental analysis.

A stimulating challenge, therefore, is to adapt or develop PIXE techniques which will become an integral or complementary part of a complex research project. Limitations on funds, available sample, sampling time, and available space often provide considerable challenge to the task of obtaining an ideal or even an acceptable sample for each of several analytical methods. Limitations such as here noted and the nature of the research problem usually require carefully coordinated sampling procedures and may require modification of commonly accepted sample collection and analytical procedures.

The PIXE method of analysis should be of considerable value in situations just described because the method not only gives multi-element results but it is versatile. It has been applied to solids, liquids, and even to gases. The area to be analyzed can be as small as a few square micrometers, if microbeam techniques are used, or as large as a square centimeter. The amount of sample material can vary from nanograms to kilograms. The sample environment can be vacuum or an atmosphere containing one of several gases including air. The sample temperature can be hot or cold. PIXE analysis is often non-destructive and is fast if the facility is properly organized.

\section{Experimental Methods}

In this section will be given a description of the PIXE analysis system, spectral analysis procedures and several general methods of target preparation used in the studies described below. Each project description will include a discussion of the specific experimental procedures used in that project.

PIXE analysis was carried out using $2-\mathrm{MeV}$ protons from a Van de Graaff accelerator. Beam currents of 50 $\mathrm{nA}$ to $200 \mathrm{nA}$ were passed through an area of $0.43 \mathrm{~cm}^{2}$ on the target. $X$-rays from the sample were detected by $\mathrm{Si}(\mathrm{Li}) \mathrm{x}$-ray spectrometer and a pulse height spectrum collected in a 1000 channel MCA controlled by a PDP-11/20 mini computer. This system and its calibration has been described in detail elsewhere. ${ }^{4} \mathrm{X}$-ray spectral data were analyzed using a computer program ANALEX. The functioning of this program and the corrections made to account for target thickness have been discussed by Nielson et. a1. ${ }^{5}$

Samples were prepared for analysis by several procedures. Some air particulate samples were collected on Nuclepore filters or were impacted on Mylar surfaces. All or a portion of these samples were mounted directly on small aluminum frames and placed in the vacuum sample chamber for analysis. In many cases the acid-soluble portion of air particulate material was extracted into a weak acid solution and then analyzed by wet chemical methods and by PIXE. Air particulate samples to be analyzed by the extraction procedure just noted were collected on Pallflex tissue quartz filters (Pall Products Corp., Putnam, Conn.) which were used both as impaction surfaces and as filters. The air particulate material was then extracted in $0.1 \mathrm{M} \mathrm{HCl}$ and $2.5 \mathrm{mM} \mathrm{FeCl}_{3}$ solution. A number of samples were also extracted in water. Details of these procedures are to be published. ${ }^{6}$ 
Samples for PIXE analysis were prepared from these and other solution samples by placing $5 \mu 1$ of the solution on a thin Mylar film and allowing it to dry. The Mylar film was previously rinsed in deionized water, immersed in $25 \% \mathrm{NaOH}$ solution for 7 min., rinsed in deionized water, immersed in $0.02 \%$ polyvinylpyrrolidone (PVP) for $2 \mathrm{~min}$, and allowed to dry in order to make it hydrophilic.

Some thick samples were used for semi-quantitative analysis by PIXE. These were prepared by combining approximately $0.40 \mathrm{~g}$ of sample, $0.20 \mathrm{~g}$ of pure ce1lulose, and $0.10 \mathrm{~g}$ of powdered $\mathrm{Al}_{2} \mathrm{O}_{3}: 3 \mathrm{H}_{2} \mathrm{O}$ containing $15.62 \mathrm{ppm} \mathrm{Y}_{2} \mathrm{O}_{3}$ as an internal standard. These materials were well mixed and then pressed into a pellet with a diameter of $2.5 \mathrm{~cm}$ and a cellulose backing. Twelve pellets were made from USGS standard rock samples ${ }^{7}$ and a NBS standard ${ }^{8}$ spiked with $\mathrm{Y}_{2} \mathrm{O}_{3}$. From these an empirical calibration curve was determined and then used to provide an estimate of the trace element content of sample material.

\section{$\underline{\text { Projects }}$}

\section{Sulfur Chemistry in a Copper Smelter Plume}

One project involved the study of sulfur chemistry in the plume from a large copper smelter located southwest of Salt Lake City, Utah. ${ }^{6}$ Some afternoons a well defined plume from the smelter would sweep in a southerly direction against the Oquirrh Mountains. A series of six sampling sites were located within the plume path along the mountain side and in the valley beyond. The first sample site was $3.9 \mathrm{~km}$ from the smelter and the last a distance of $60 \mathrm{~km}$ from the smelter. At each site the following samples and data were collected: meteorological information, $\mathrm{SO}_{2}$ concentrations and air particulate material. The primary aerosol sample was taken with a Sierra Instruments, Inc., high volume cascade impactor (series 230) with three impaction stages and a back-up filter. Both the impaction surfaces and the filter were of tissue quartz as was noted above. The center strip of the tissue quartz collection surface on each impaction stage was removed and replaced with a strip of doublestick cellulose tape (DSCT) (3M Manufacturing Co.). Particles were collected directly on one half the length of this tape and were analyzed by ESCA. The other half of the DSCT was covered with $1 / 4$ mil Mylar which contained a thin film of petroleum jelly on which the particles were collected. A portion of the Mylar strip was analyzed without further preparation by PIXE analysis. Particulates on the tissue quartz were extracted as discussed in the experimental section.

In addition to PIXE the following analytical methods were used in the analysis of the particulate material: thermometric analysis using highly sensitive calorimeters, ion exchange chromatography, ESCA analysis, SEM and ion microprobe analysis, and Mössbauer analysis. While only the PIXE analyses will be emphasized in this paper it should be noted that PIXE analysis was a support to the other techniques and that the sampling procedure was designed to provide a proper sample for each of the techniques while keeping within the constraints of time, effort and equipment.

The majority of the particulate mass was found on the impaction stage containing particles in the 0.5$1.5 \mu \mathrm{m}$ size range and the discussion below refers primarily to this size fraction.

It was observed that the $A$ s in the background samples was negligible but could be determined in all

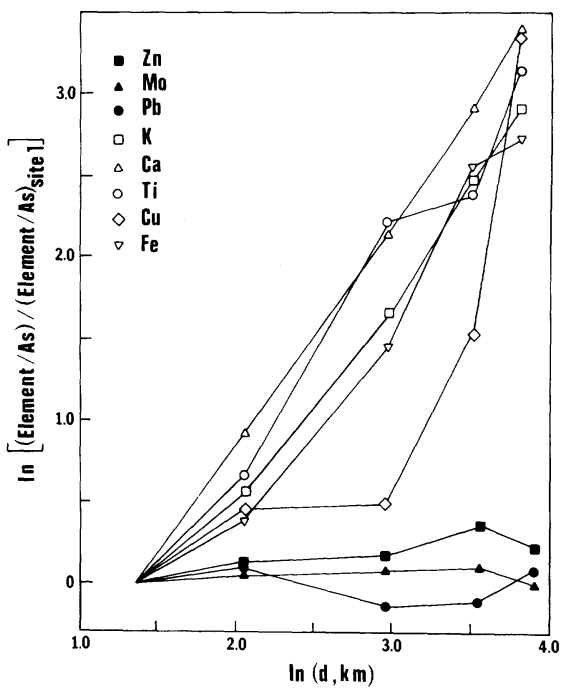

Figure 1. Mole ratio of several elements to As in 0.5-1.5 $\mu \mathrm{m}$ particles as a function of distance from the smelter. From Ref. 6.

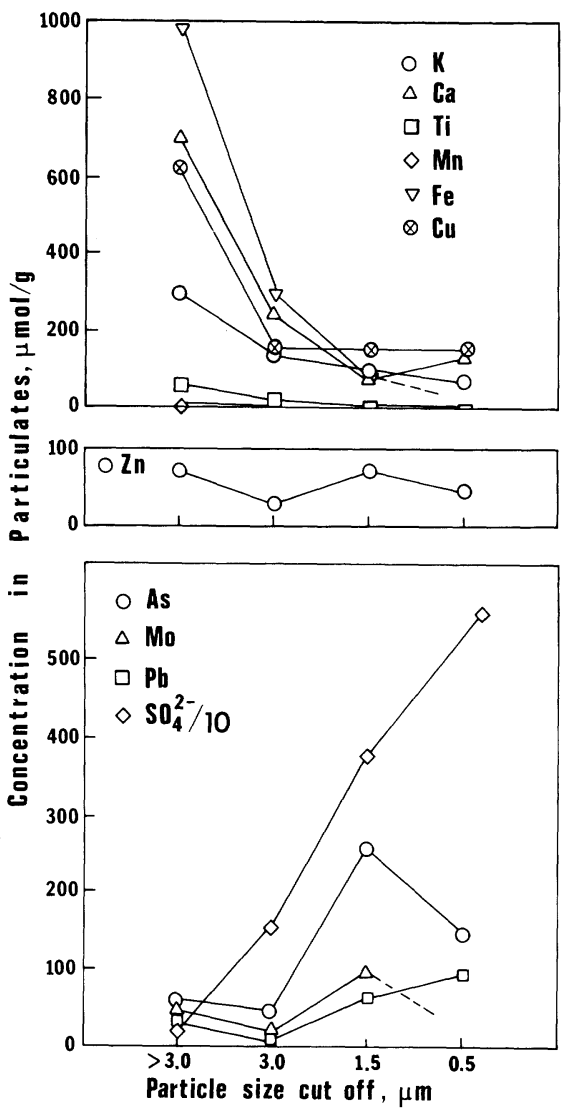

Figure 2. Concentration of sulfate and elements in particulate matter collected at site 1 as a function of particle size. From Ref. 6. 
samples taken within the plume. Therefore As was selected as a conservative plume tracer. Figure 1 shows the ratio of element concentration to As concentration at each site normalized to the ratio at site 1 (nearest the smelter) as a function of the distance from the smelter. $\mathrm{Zn}$, Mo and $\mathrm{Pb}$ show a constant value, suggesting that their primary source was the same as that of As, i.e. the smelter. $\mathrm{K}, \mathrm{Ca}, \mathrm{Ti}$ and $\mathrm{Fe}$ increase steadly with increasing distance from the smelter suggesting that they were introduced into the plume as ambient air mixed with the plume. These observations support the use of $A s$ as a conservative plume tracer and the use of the As concentration in the calculation of plume dilution.

Element concentrations as a function of particle size are shown in Figure 2. Concentrations of $\mathrm{K}, \mathrm{Ca}$, $\mathrm{Fe}, \mathrm{Cu}$ and apparently $\mathrm{Ti}$ and $\mathrm{Mn}$ all decrease with decreasing particle size. Concentrations of As, Mo, $\mathrm{Pb}$ and $\mathrm{SO}_{4}^{2}$ increase with decreasing particle size.

In addition to other elements, $\mathrm{Ca}, \mathrm{As}$ and $\mathrm{SO}_{4}^{2-}$ were determined in eight background samples and the $\mathrm{SO}_{4}^{2}: \mathrm{Ca}$ and the As: $\mathrm{Ca}$ ratios were found to be $1.0 \pm 0.6$ and $0.005 \pm 0.007$ respectively. Futhermore, it was determined that the concentration of $\mathrm{Ca}$ in the plume near the source was about $0.02 \mu \mathrm{mole} / \mathrm{mg}$ of particulate matter. This contribution of $\mathrm{Ca}$ due to the plume would be further reduced as the plume was diluted. These observations led to the following conclusions. The As in the ambient air particulates was small enough to be neglected in comparison to that found in the smelter plume. Ca found in the plume at various distances from the source could be assumed to come entirely from the ambient air and the $\mathrm{SO}_{4}^{2-}$ coming from the ambient air had a concentration equal to that of the $\mathrm{Ca}$. This was most important in order to determine the amount of sulfate being formed from $\mathrm{SO}_{2}$ in the plume.

Some important observations concerning the sulfur species were made. While the As concentration in the air particulates decreased with time as the plume moved away from the source, the concentration of S(IV) increased and the concentration of $\mathrm{SO}_{4}^{2-}$ decreased significantly slower than the As. Therefore, both species of sulfur particulate material were being formed in the plume as it aged. It was found in this study that S(IV) formed stable complexes with $\mathrm{Fe}$ and $\mathrm{Cu}$ found both in the plume and in ambient particulates and that the amount of the complexes formed was controlled by chemical equilibrium. The amount formed was directly proportional to the concentration of $\mathrm{SO}_{2}(\mathrm{~g})$ and of particulate $\mathrm{Cu}+\mathrm{Fe}$ and was inversely proportional to the particulate acidity. The formation of $\mathrm{SO}_{4}^{2}$ was found to be controlled by chemical kinetics and may be described by a mechanism which is first order in $\mathrm{SO}_{2}(\mathrm{~g})$. The formation did not depend on plume expansion nor on particulate acidity, metal content or $\mathrm{S}(\mathrm{IV})$ content. The $\mathrm{SO}_{4}^{2-}$ formed was mainly in the $<0.5 \mu \mathrm{m}$ particle size.

\section{Effluents From a High-temperature, Entrained-flow} Gasifier

In a recently completed project, measurements were made to determine the presence and amounts of potential inorganic and organic pollutants in the effluents of a high-pressure, high-temperature, entrained-flow gasifier. 9 The project was carried out in cooperation with Eyring Research Institute where the gasifier was being developed. Pulverized coal was introduced into the gasifier in a gas stream and mixed with superheated steam and oxygen. The reaction was carried out at pressures of 50 to $300 \mathrm{psig}$ and temperatures of $1200^{\circ}-1500^{\circ} \mathrm{C}$. The products were partially cooled, slag and some fly ash were removed, and then the product gas was cleaned and cooled in a water scrubber column.

Samples for analysis were taken from (a) the product gas stream, (b) the scrubber effluent water, (c) the gas evolved on depressurization of the scrubber water, and (d) the particulate matter filtered from the scrubber water. A few samples of coal and slag were also analyzed. Sets of samples were taken for several operating conditions. The different operating conditions were achieved by varying coal type, coal feed rate, reactor pressure, oxygen to coal ratio, and steam to coal ratio.

The results of the PIXE analyses are summarized here. It should be emphasized, however, that PIXE was just one of many methods of analysis and was used in a supporting roll in the project. Other methods of analysis were gas chromatographic/mass spectrometry, $\mathrm{X}$-ray fluorescence, thermometric titrimetry, ion chromatography, atomic absorption spectroscopy and the use of Dräger Tubes (SKC West, Fullerton, CA) for some gas analyses. A considerable effort was required to design sampling procedures which provided a proper sample for each of these analytical methods and at the same time satisfied the constraints of time and resources available for the project.

Table 1. indicates the concentrations of several elements in particulates filtered from the product gas stream. The data shown represent the mean values determined in five separate gasifier experiments. The concentrations are comparable to those found in ambient air. ${ }^{10}$ The values for $\mathrm{S}, \mathrm{Cl}, \mathrm{K}$, and $\mathrm{Ca}$ fall between those typical of urban air and those typical of air in remote regions. The values for $\mathrm{Cr}, \mathrm{Fe}, \mathrm{Ni}$, $\mathrm{Cu}, \mathrm{Zn}$ and $\mathrm{Br}$ are about average for urban air. The differences in these two sets of elements with respect to urban aerosol levels may arise from fractionation processes in the combustion and scrubbing steps or they could be due to erosion of the metal parts of the gasifier system.

Table 2. lists the concentrations of a number of elements and ions found in the scrubber water after removing the soot by filtration. The values are means calculated from eleven gasifier experiments. Se, As and $C d$ were determined by atomic absorption spectrometry and the ions were determined by ion chromatography. The rest of the elements were determined by PIXE. Concentrations of all species listed with perhaps the exception of $\mathrm{NH}_{4}^{+}$, are well below those required by clean water standards. This means that after the relatively simple step of filtration, the scrubber water could be discharged directly into it culinary water system. Perhaps some treatment for $\mathrm{NH}_{4}^{+}$ would be necessary.

Table 3. lists the concentrations of several elements in the soot filtered from the scrubber water. The first two rows of data relate to mean values for seven gasifier experiments. The last three rows of data show the values determined for the soot, coal and slag of experiment eleven. There was a considerable concentration of the elements in the soot. This demonstrates that most of the pollutants are incorporated into the soot and filtered out of the effluent water. This surprising result was observed to be true for organic species as well for the inorganic materials discussed here.

The results of this study lead to the conclusion that both the product gas and effluent water streams were exceptionally clean which makes the process studied attractive from an environmental point of view. The only pollutant problems of concern were the 
pressence of some $\mathrm{H}_{2} \mathrm{~S}$ in the product gas, the level of $\mathrm{NH}_{4}^{+}$dissolved in the water, the removal of soot from the water, and the final disposal of the ash.

\section{Acknowledgements}

Appreciation is expressed to personnel of the Utah Copper Division of Kennecott Minerals Company and to personnel of Eyring Research Institute. These projects were funded by U.S. Department of Energy contracts No. EY-76-S-02-2988 and No. EE-77-S-02-4377.

\section{References}

1. S.A.E. Johansson and T.B. Johansson, Analytical application of particle induced X-ray emission, Nucl. Instr. \& Meth. 137, 473 (1976).

2. Proc. Int. Conf. on Particle induced X-ray emission and its analytical applications, Lund 1976, Nucl. Instr. \& Meth. 142, (1977).

3. Proc. 2nd Int. Conf. on Particle induced X-ray emission and its analytical applications, Lund 1980, Nucl. Instr. \& Meth., to be published.

4. N.F. Mangelson, M.W. Hill, K.K. Nielson, D.J. Eatough, J.J. Christensen, R.M. Izatt and D.0.
Richards, Proton induced X-ray emission analysis of Pima Indian autopsy tissues, Anal. Chem. 51, 1187 (1979).

5. K.K. Nielson, M.W. Hill and N.F. Mangelson, Calibration and correction methods for quantitative proton-induced X-ray emission analysis of autopsy tissues, Advan. X-ray Anal. 19, 511 (1976).

6. D.J. Eatough, J.J. Christensen, N.L. Eatough, M.W. Hill, T.D. Major, N.F. Mangelson, M.E. Post, J.F. Ryder and L.D. Hansen, Sulfur chemistry in a copper smelter plume, submitted to Atmos. Environ. (1980).

7. F.J. Flanagan, 1972 values for international geochemical reference samples, Geochim. et Cosmochim. Acta 37, 1189 (1973).

8. National Bureau of Standards standard reference material 1571, orchard leaves, Aug. 15, 1976.

9. L.D. Hansen, L.R. Phillips, N.F. Mangelson and M.L. Lee, Analytical study of the effluents from a high-temperature entrained flow gasifier, FUEL 59, $323(1980)$.

10. J.M. Jaklevic and R.L. Walter, Comparison of minimum detectable limits among $X$-ray spectrometers, in X-ray Fluorescence Analysis of Environmental Samples, ed. T.G. Dzubay (Ann Arbor Science Pub., Inc., Ann Arbor 1977) pp. 63-75.

Table 1. Composition of particulate matter in the product gas.

$\begin{array}{lrrrrrrrrrrr}\text { Elements } & \mathrm{S} & \mathrm{Cl} & \mathrm{K} & \mathrm{Ca} & \mathrm{Cr}^{1} & \mathrm{Fe}^{1} & \mathrm{Ni} & \mathrm{Cu} & \mathrm{Zn} & \mathrm{Br} \\ \mathrm{ppb},{ }^{2} \text { mean } & 2.9 & <0.5 & 0.23 & 1.3 & 0.45 & 4.3 & 0.25 & 1.27 & 0.42 & 0.15 \\ \mathrm{s.d} . \quad(\mathrm{N}=5) & \pm 2.9 & & \pm 0.23 & \pm 1.0 & \pm 0.19 & \pm 5.4 & \pm 0.20 & \pm 0.84 & \pm 0.30 & \pm 0.17\end{array}$

${ }^{\mathrm{T}} \mathrm{Blank}$ values were in error and were not subtracted from these data.

${ }^{2} \mathrm{ppb}$ by weight of product gas $\simeq \mathrm{mg} / \mathrm{m}^{3}$

Table 2. Filtered scrubber water composition.

\begin{tabular}{|c|c|c|c|c|c|c|c|c|c|c|c|c|c|}
\hline Elements & $\mathrm{Si}$ & S & $\mathrm{C} 1$ & $\mathrm{~K}$ & $\mathrm{Ca}$ & $\mathrm{Ti}$ & $\mathrm{Cr}$ & Mn & $\mathrm{Fe}$ & $\mathrm{Ni}$ & $\mathrm{Cu}$ & $\mathrm{Zn}$ & $\mathrm{Br}$ \\
\hline $\mathrm{ppm}$, mean & 2 & 5.1 & 2.5 & 0.52 & 37.7 & $<0.1$ & $<0.1$ & $<0.05$ & 3.2 & $<0.1$ & 0.023 & 0.59 & 0.10 \\
\hline s.d. $\quad(N=13)$ & & \pm 3.7 & \pm 4.7 & \pm 0.45 & \pm 23.0 & & & & \pm 4.7 & & \pm 0.027 & \pm 0.98 & \pm 0.09 \\
\hline
\end{tabular}

$\begin{array}{lrrrrrrrrrrrrr}\text { Elements } & \mathrm{Sr} & \mathrm{Se}^{1} & \mathrm{As}^{1} & \mathrm{Cd}^{1} & \mathrm{Na}^{+} & \mathrm{NH}^{+} & \mathrm{F}^{-} & \mathrm{Cl}^{-} & \mathrm{NO}_{2}^{-} & \mathrm{Br}^{-2} & \mathrm{NO}_{3}^{-} & \mathrm{SO}_{4}^{=} & \mathrm{HCO}_{3}^{-} \\ \text {ppm, mean } & 0.76 & <1.2 & 1.0 & 0.20 & 0.81 & 48 & 0.10 & 5.0 & <0.9 & <2.5 & 1.5 & 7.0 & 188 \\ \text { s.d. (N=13) } & \pm 0.97 & & \pm 1.4 & \pm 0.37 & \pm 0.75 & \pm 12 & \pm 0.75 & \pm 3.9 & & & \pm 1.4 & \pm 7.0 & \pm 135\end{array}$

${ }^{1} \mathrm{ppb}$ for these elements.

${ }^{2} \mathrm{Br}^{-}+\mathrm{SO}_{3}$ are both included here.

Table 3. Trace elements in scrubber water soot (solid pellet technique).

\begin{tabular}{lrrrrrrrrrr} 
Elements & $\mathrm{K}$ & $\mathrm{Ca}$ & $\mathrm{Ti}$ & $\mathrm{Cr}$ & $\mathrm{Mn}$ & $\mathrm{Fe}$ & $\mathrm{Cu}$ & $\mathrm{Zn}$ & $\mathrm{Br}$ & $\mathrm{Sr}$ \\
ppm, mean & 2000 & 5000 & 1700 & 48 & 30 & 7700 & 180 & 50 & 46 & 280 \\
s.d. (N=7) & \pm 1100 & \pm 2800 & \pm 600 & \pm 26 & \pm 24 & \pm 1500 & \pm 100 & \pm 18 & \pm 31 & \pm 45 \\
Run 11 soot & 1240 & 48200 & 2640 & $\mathrm{ND}^{1}$ & 540 & 7630 & 300 & 50 & 25 & 1600 \\
Run 11 coal & 200 & 10000 & 500 & $\mathrm{ND}^{1}$ & 100 & 1700 & 5 & 3 & 15 & 250 \\
Run 11 slag & 500 & 24000 & 1060 & $\mathrm{ND}^{1}$ & 300 & 7200 & 15 & $\mathrm{ND}^{1}$ & 50 & 600 \\
\hline
\end{tabular}

